\title{
Power and Principle in Constitutional Law ${ }^{*}$
}

\author{
Pavlos Eleftheriadis
}

Is sovereignty relevant to modern government? This is a question of great theoretical interest as well as of great practical interest. The current debates on the future of the European Union after the British referendum have touched on issues of sovereignty. Many people in the United Kingdom are worried, for example, about what they perceive to be an incursion into sovereignty by European institutions and believe that a withdrawal from the EU will restore sovereignty. This is what Prime Minister Theresa May said at a speech to the Conservative Party Conference in September 2016. She promised that leaving the EU would make the United Kingdom once again a fully 'sovereign' state. Does it make sense to speak of sovereignty in this way? Or is the ideal of absolute self-government a mirage? Can the idea of sovereignty carry the political burden placed upon it?

Many important philosophers and legal scholars believe that it cannot. The distinguished legal philosopher Neil MacCormick famously argued that processes of 'division' and 'combination' had already taken place in such a way that we are now 'beyond the sovereign state'. ${ }^{1}$ MacCormick believed that international institutional developments, including the emergence of the legal structures of the European Union with the twin principles of the direct effect and supremacy of EU law, had rendered sovereignty largely irrelevant to modern states. In his view sovereignty had stopped being a useful idea, since a well-ordered state under the rule of law always disperses power to various bodies and sources both inside as well as outside its borders. ${ }^{2}$ So we cannot become fully sovereign, in the sense of concentrating power in one institution or body. That is not how modern states work.

It seems to me that this view of the fragmentation of power and irrelevance sovereignty is now a dominant view inside the EU. An example of this attitude to sovereignty is the Opinion of the Court of Justice of the European Union on Accession to the European Convention on Human Rights, which declared that the law of the European Union is 'autonomous' from both member state constitutional law and public international law. ${ }^{3}$ If European Union law is 'autonomous' it

* An earlier version of this essay was presented as a lecture at the Philosophy Faculty at the University of Leuven as part of the series 'Sovereignty in Transition'. I am very grateful to Raf Geenens and all other participants for a very fruitful exchange.

1 Neil MacCormick, Questioning Sovereignty: Law, State and Nation in the European Commonwealth (Oxford: Oxford University Press, 1999), 133. I made a similar argument in Pavlos Eleftheriadis, 'Law and Sovereignty,' Law and Philosophy 29 (2010): 535.

2 MacCormick, Questioning Sovereignty, 129.

3 See Opinion 2/2013, Opinion pursuant to Article 218(11) TFEU - Draft international agreement Accession of the European Union to the European Convention for the Protection of Human Rights and Fundamental Freedoms, Opinion of the Court (Full Court) of 18 December 2014, ECLI:EU:C: 2014:2454. 
does not derive form sovereignty in either of its manifestations: domestic or international. EU law is thus one element in a fragmented universe of legal structures where it is pointless to look for a foundational or ultimate rule.

Other theorists, however, disagree with this dismissal of sovereignty. Martin Loughlin, one of the leading scholars of public law in Britain, has criticised MacCormick for failing to appreciate the true nature of sovereignty. He believes that sovereignty as power is an essential precondition of any legal order. ${ }^{4}$ Loughlin calls this view a 'relational' concept of sovereignty because for him political power is 'generated by the relationship between rulers and ruled'. ${ }^{5}$ Loughlin's ambitious argument tells us that MacCormick's 'errors' were due to his legal positivist theoretical orientation and his insistence that political sovereignty could be reduced to a matter of law alone. Loughlin's view, by contrast, is based on social relations. The argument is based on an idea of 'constituent power' which resides with the people or the nation, and which is the 'repository of sovereignty in those regimes that adopt formal constitutions and allocate legal authority to designated organs of government'. ${ }^{6}$ In Loughlin's view sovereignty, conceived as constituent power, is an essential element of all political activities and processes and is the 'generative principle' of public law. ${ }^{7}$

The disagreement between MacCormick and Loughlin is about the interplay between power and principle in constitutional law. It reminds us of the subtly different but also overlapping uses that the idea of power is being put to in legal and political theory. Loughlin uses sovereignty to describe power, namely the physical but also mental power that underlies the political essence of the state. The power of the people or of the multitude, Loughlin says, is the essential political core of state law. ${ }^{8}$ By contrast, MacCormick deploys sovereignty as a technical concept that we use to interpret power or claims of right, namely the legal processes and constitutions that organise the state.

One could see this as a sign that there is no disagreement between them, since they are talking about different things. Loughlin is interested in power. MacCormick is interested in legal ideas. But such a conclusion would be a mistake. Loughlin and MacCormick are looking at the same thing. They are looking at the way in which law and power interact in setting up a constitution. Their subject matter is sovereignty. When one looks at their views in detail it becomes clear that for neither of them is there an object 'power' or an object 'law' that can be examined separately from one another. They are thus in agreement that some factual preconditions make law possible and that in some way the legal usage supervenes on the

4 Martin Loughlin, The Idea of Public Law (Oxford: Oxford University Press, 2004), 89-90.

5 Loughlin, The Idea of Public Law, 90.

6 Ibid., 90.

7 Ibid., 113.

8 See Loughlin, The Idea of Public Law, 113, where he writes: 'Constituent power cannot be entirely absorbed into norms nor wholly reduced to fact. It emerges because of the unbridgeable gulf that exists between governors and governed, and it expresses a form of power that mediates between the three orders of the political'. 
political process and changes it. Their conclusions, however, differ dramatically. For MacCormick, sovereignty was once able to guide constitutional law but has now been replaced by other ideas. Loughlin denies that this change has taken place.

In this essay I will look at this disagreement in order to unearth some of the complexities of constitutional law. I will be focusing on the ways in which power and principles interact in the creation of a constitution. My argument follows the practical and constructivist account of law as a project of deliberation, which I set out in an earlier book. ${ }^{9}$ I will outline here a practical and constructivist account of constitutional law which is similar to the account I gave there of legal rights. I call it the 'deliberative constitution'. I will defend MacCormick because I think he draws the correct conclusions about power and sovereignty. Sovereignty is just another construction of practical reason that features in the process of legal deliberation on matters of constitutional law. But I will also defend Loughlin, because I will argue that real comprehensive and coercive power remains one of the most important dimensions and preconditions of constitutional law. Because law is a self-reflective reason that deliberates on what ought to be done and ultimately what ought to be enforced through the mechanisms of the state, all its basic concepts emerge from or through power.

\section{Legal sovereignty}

I start with legal sovereignty. What is it? Modern law provides us with no guidance. Most constitutional discussions of sovereignty refer to 'popular sovereignty', not to sovereignty itself. Popular sovereignty, however, is a constitutional principle, with a separate content. It is connected not to the theory of law but to theories of democracy. Legal sovereignty in this simple sense has had a sophisticated legal development in only one case, namely the constitutional law of the United Kingdom. The great Victorian constitutional scholar A.V. Dicey has said that parliamentary sovereignty was 'an undoubted legal fact.' ${ }^{\text {10 }} \mathrm{He}$ said it was 'the dominant characteristic of our political institutions'. ${ }^{11}$ For Dicey, the principle of parliamentary sovereignty had priority over all other principles of constitutional law in that an Act of Parliament could not ever be challenged by a court on the basis of any other principle. This would be the case even if this Act of Parliament violated constitutional principles, for example, if it abolished the court system or

9 Pavlos Eleftheriadis, Legal Rights (Oxford: Oxford University Press, 2008).

10 A.V. Dicey, Introduction to the Study of the Law of the Constitution, 8th ed. (London: Macmillan, 1915; reprinted Indianapolis: Liberty Fund, 1982), 24. For the idea of sovereignty in English law, see Jeffrey Goldsworthy, The Sovereignty of Parliament: History and Philosophy (Oxford: Clarendon Press, 1999); J. W. F. Allison, The English Historical Constitution: Continuity, Change and European Effects (Cambridge: Cambridge University Press, 2007); Alison Young, Parliamentary Sovereignty and the Human Rights Act (Oxford: Hart, 2008). For an effective criticism of the Diceyan view of the United Kingdom constitution, see T. R. S. Allan, The Sovereignty of Law: Freedom, Constitution and the Common Law (Oxford: Oxford University Press, 2013).

11 Dicey, Introduction, 3. 
imposed retroactive criminal punishment. It is important to emphasise that Dicey's sovereignty is something very different from popular sovereignty.

As is well known, this is a unique position in world constitutionalism. Most states have written constitutions that set some principled limits to the power of legislatures, even if they do not provide judicial enforcement of those limits. In Dicey's theory, no legal limits are even conceivable. The legal sovereign, whose sovereignty is a matter of fact, is incapable of restriction. Dicey defended this view on the basis of a deeper theory of law which he took from John Austin. Law, for Austin, is created by the actions and words of the sovereign, whenever these are effectively communicated to the subjects by way of 'commands'. He said that a legal order exists when a sovereign obeys the commands of no one and whose commands are obeyed by everyone. ${ }^{12}$ Austin wrote that 'a command is distinguished from other significations of desire, not by the style in which the desire is signified, but by the power and the purpose of the party commanding to inflict an evil or pain in case the desire be disregarded' ${ }^{13}$ In any legal system, Austin had argued, the sovereign is the only source of law. Dicey rejected some aspects of Austin's theory but accepted the most fundamental, namely the premise that the foundation of the legal order is the political fact of the existence of the sovereign. ${ }^{14}$ This is a 'simple fact' theory of sovereignty or 'factual sovereignty' for short.

Austin's theory of sovereignty is, however, a very inadequate theory of law. H.L.A. Hart pointed out that under Austin's theory there cannot be any stable framework of government and no constitution since there can be no distinction between a higher law of the constitution and ordinary law. ${ }^{15}$ If there is a sovereign, then every desire or wish he or she may have is law. Anything the sovereign says about the form of government and law is fully revised by his or her next pronouncement. Under such a framework there cannot be a constitution or constitution-making, since the fundamental law is always superseded by the sovereign's implicit or explicit wishes. Hart explained that Austin's theory was wholly incapable of accommodating a system where power was divided between the various branches of government and, indeed, exercised by the electors. The problem was also identified by Richard Latham when he noted that 'the King, Lords and Commons meeting in a single joint assembly, and voting by majority, or even unanimously, could not enact a statute'. ${ }^{16}$ Legislation requires the Queen in Parliament acting according to the standing rules of law-making. Such rules have no place in

12 See John Austin, The Province of Jurisprudence Determined, ed. Wilfrid E. Rumble (Cambridge: Cambridge University Press, 1995). For very illuminating discussions of Austin's legal philosophy, see John Austin, The Legacy of John Austin's Jurisprudence, ed. Michael Freeman and Patricia Mindus (Dordrecht: Springer, 2012).

13 Austin, The Province, 21.

14 Dicey noted that '[a]ll the speculative difficulties of placing any limits whatever on sovereignty has been admirably stated by Austin and by Professor Holland'; Dicey, Introduction, 18.

15 H.L.A. Hart, The Concept of Law, 2nd ed. (Oxford: Oxford University Press, 1993).

16 R.T.E. Latham, The Law and the Commonwealth (Oxford: Oxford University Press, 1949), 523, note 3 . 
Austin's view of law. ${ }^{17}$ To accommodate our ordinary experience of law and the distinction between higher and ordinary law, we need a distinction between laws that define what law is, or constitutional laws, and other laws.

In Hart's view, we need a distinction between primary and secondary rules, i.e. rules of conduct and rules about rules. ${ }^{18}$ Such a distinction was impossible for Austin, for whom all legal rules were commands to do something. For Hart by contrast the very idea of a legal system depends on a structure of secondary rules, namely rules of competence that outline the offices of executive power, the legislature and the judiciary, and that tell us how law is made. This view appears consistent with British constitutional law. ${ }^{19}$ In the United Kingdom the power to make laws is divided between the House of Commons, the House of Lords and the Monarch, a process which constitutional lawyers call 'the Queen in Parliament'. Such divided power was impossible to accommodate under Austin's theory, however, and Austin himself was led to the conclusion that the sovereign in the United Kingdom was only the body of 'electors' ${ }^{20} \mathrm{H}$. L. A. Hart endorses, therefore, a complex fact view of sovereignty according to which legal sovereignty is a legal office, which is the result of some fact of convergence of officials in attitude and belief. In this analysis, sovereignty is not itself a fact, as Austin had argued. It is a legal title, because law is made by appropriate bodies, according to appropriate procedures set out in the rule of recognition.

This is the view of sovereignty endorsed by Neil MacCormick. It is also the theory attacked by Loughlin. Hart explained the continuity of legislative authority by means of a 'firmly established rule' which gives a new legislator the 'right' to legislate. Such a rule exists because it is 'generally accepted by the group' during the lifetime of the incumbent legislator. Under such a general rule, 'Rex I is merely the particular person so qualified at a particular time'. ${ }^{21}$ So for Hart, it is not power that gives rise to law. The law is created by a separate complex fact, namely the set of beliefs and attitudes or cognitive patterns that signal support for appropriate secondary rules, which Hart calls 'rules of recognition', 'rules of

17 Latham concluded that in the United Kingdom the sovereign is not an 'actual person' but a body whose designation 'must include the statement of rules for the ascertainment of his will, and those rules, since their observance is a condition of the validity of his legislation, are rules of law logically prior to him'; see Latham, The Law \& the Commonwealth, 523 (footnotes omitted).

18 Hart, The Concept of Law, 79-99.

19 The appearance may be deceiving. For a persuasive critique of the Hartian view of the British Constitution, see Allan, The Sovereignty of Law.

20 Austin spent a great deal of time trying to explain this in ever more implausible ways. For a detailed discussion, see Pavlos Eleftheriadis, 'Austin and the Electors,' Canadian Journal of Law and Jurisprudence 24 (2011): 441.

21 Hart, The Concept of Law, 58. (cf. footnote 18). 
change' and 'rules of adjudication', which jointly create the legal system. Power makes law only through the mediation of such rules. ${ }^{22}$

MacCormick explicitly endorsed this legally defined view of sovereignty: 'Sovereign power is that which is enjoyed, legally, by the holder of a constitutional power to make law, so long as the constitution places no restrictions on the exercise of that power...'23 Many constitutional lawyers agree with this general point. ${ }^{24}$ They are of the view that a constitution depends on rules of competence that apply to itself and to the rest of the law. From this idea it also follows that all offices of government, contrary to what Austinian sovereignty requires, divide power into different components that are kept separate by legal principles and rules, ultimately monitored by the courts. This is the familiar constitutional principle of the separation of powers. Under Hart's model of rules, no office is truly outside the law and there is no sovereign or any other ultimate 'creator' of the law. All law is made by impersonal secondary rules, the rule of recognition and the rules of adjudication and change. For Hart, legal sovereignty is true because it is subject to the rule of recognition, not the other way round.

\section{Constitutional supremacy}

Hart's idea of law as a system of rules gives rise to a third possibility, besides the two conceptions of sovereignty already mentioned. This is the possibility that law recognises the supremacy of certain rules and institutions, without any resulting sovereignty. Under Hart's own system it is perfectly conceivable to have power distributed according to a fundamental rule of recognition in such a way that no single person or single institution enjoys ultimate power. This is the position reached by MacCormick, captured by the idea of a 'post-sovereign' state. In this model, every institution and office is controlled by every other institution and office, under a system of checks and balances that may involve both domestic and international institutions.

We may call this possibility 'constitutional supremacy'. This is a common view in the United States, where the idea of sovereignty plays a secondary role. The American constitutional scholar Christopher Eisgruber, for example, speaks of a democratic constitution as a mechanism for breaking up power: 'If constitutionmakers want to establish a democratic system of government, they should design

22 Hart's view is a continuation of earlier theories of legal sovereignty. See W. J. Rees, 'The Theory of Sovereignty Restated,' 496; H. W. R. Wade, 'The Basis of Legal Sovereignty,' Cambridge Law Journal 172 (1955). The same view is endorsed by Jeffrey Goldsworthy, for whom 'rather than being a transcendent creator of all laws, a sovereign law-maker is itself created by fundamental laws'; Jeffrey Goldsworthy, The Sovereignty of Parliament: History and Philosophy (Oxford: Oxford University Press, 1999), 14.

23 MacCormick, Questioning Sovereignty, 127. Nevertheless, MacCormick concludes that 'sovereignty is neither necessary to the existence of law and state nor even desirable' (p. 129).

See for example Goldsworthy, The Sovereignty of Parliament. 
institutions that are impartial rather than majoritarian'. ${ }^{25}$ Eisgruber rejects the British model of sovereignty of an 'omnipotent national Parliament' and proposes that a more satisfactory constitution would choose instead 'to fragment power in order to increase the likelihood that the government will be responsive to the interests of minorities as well as majorities' ${ }^{26}$ For this view of the constitution, sovereignty is actually irrelevant. Eisgruber argues that the meaning and purpose of a constitution is a democratic one, namely to create 'a range of institutions to represent a people who would otherwise have no satisfactory way to act collectively'. ${ }^{27}$ We gain nothing by supposing a source of overwhelming political power anywhere in that institutional framework.

As I understand it, Loughlin's argument is that both MacCormick and Eisgruber fail in their attempt to escape the idea of sovereignty. At most, MacCormick's 'post-sovereign' state describes a momentary retreat of the 'constituent' power that makes constitutional stability possible. And whatever their moral ambition, Eisgruber's democratic principles remain at the mercy of underlying political powers. Loughlin's claim is that 'constituent power' is the 'repository of sovereignty' and that this is true even where power is dispersed into different branches of government. ${ }^{28}$ It is a power that constitutes not only the legal system, but the state itself. Loughlin writes that constituent power is the 'generative principle' of modern constitutional arrangements and gives 'juristic expression to those forces that constantly irritate the formal constitution, thereby ensuring it is able to perform its political function'. ${ }^{29}$ I believe that Loughlin is wrong about this point. He is wrong to say that sovereignty creates law. He is correct, however, to say that law is ultimately about power, is born of power and has the duty of harnessing power for the sake of justice. This is what I will seek to explain in the next section.

\section{The problem of amendment}

Loughlin's argument is best understood when we apply it to the question of constitutional change. The question here is not what motivates or causes constitutional change. The answer to that is often simple. What causes constitutional change is a set of unsettling social and economic developments. When such developments take place, people will use their power to change the constitution. The question, rather, asks by what process a valid change in the constitution is made. How is the constitution amended in law?

This is the area where Loughlin believes that sovereignty always plays its part. After examining a series of historical examples and theories of the constitution, Loughlin suggests that constitutional change cannot follow legal constraints but

Christopher L. Eisgruber, Constitutional Self-Government (Cambridge, Mass.: Harvard University Press, 2001), 19.

26 Eisgruber, Constitutional Self-Government, 19.

27 Ibid., 206.

28 Loughlin, The Idea of Public Law, 90.

29 Ibid., 100. 
is always subject to social processes uncontrolled by law. He argues that constitutional validity is not a matter of 'norms', but a matter of constituent power or practice, which cannot be captured by legal forms. While he admits that 'constituent power' is not a purely brute or factual power, he nevertheless concludes that constituent power is the power that gives constitutions their open, provisional, and dynamic qualities, keeping them responsive to social change and reminding us that the norm rests ultimately on the exception'. ${ }^{30}$

Loughlin's argument has an obvious connection to Hart's. Hart too relies on some non-legal event, a set of facts, a political episode or a general convergence of attitude and belief, as the foundation of the legal order. Loughlin observes, however, that any such factual foundation creates radical instability. If the constitution were created by the kind of social agreement described by Hart, then it would change every time that social agreement changed. It would not just be open to the possibility of change, but it would have to be taken to have changed merely by the change of opinion. Under Hart's framework we would have to accept that there are always two ways of amending the constitution. The first way would be through processes of law, i.e. through the formal processes of constitutional amendment as provided by the written constitution. The second way would be through a change in the relevant constitution-generating fact, i.e. through the relevant political episode or the type of common allegiance and belief that sustained the rule of recognition. This constitution-generating change would occur at the more fundamental level underpinning the law (or, more accurately, causing it to happen) through a shift in the social pattern which was the basis of the rule of recognition and which Loughlin calls 'constituent power'. Every such change would amend the rule of recognition and thus create a new constitution. Constituent power must be ever present.

But if such a second avenue of constitution-making were possible, it would be a constant possibility. Law's existence and authority would thus depend on ascertaining that relevant social facts were true. How could we ever assume that the Constitution was still in place, without checking first for the underlying factual background? In Hart's account, for example, everything should depend on the relevant facts about people's attitudes and beliefs and their required convergence. Hart's theory thus makes the constitution entirely unique. Unlike all other laws, the constitution cannot rest on its validity. It would exist only if people believed that it existed. Its legal status would be an empirical fact, not a proposition of law. It would thus be the most unstable of laws.

This is in fact the view of one of the leading British constitutional theorists of the twentieth century, Sir William Wade. In Wade's view, the unwritten constitution of the United Kingdom could change only through extra-legal, revolutionary

30 Loughlin, The Idea of Public Law, 113. For a parallel argument see Martin Loughlin, 'Constituent Power Subverted: From English Constitutional Argument to British Constitutional Practice,' in The Paradox of Constitutionalism: Constituent Power and Constitutional Form, ed. Martin Loughlin and Neil Walker, (Oxford: Oxford University Press, 2007), 27-48. 
moments that could not be sanctioned by existing law. ${ }^{31}$ Wade believed that if no statute could establish the rule that courts ought to obey Acts of Parliament without circularity, then, similarly, no statute could abolish or amend that rule either. He concluded that the fundamental constitutional rule of parliamentary sovereignty 'is above and beyond the reach of statute ... because it is itself the source of the authority of statute. This puts it into a class by itself among rules of common law, and the apparent paradox that it is unalterable by Parliament turns out to be a truism'. ${ }^{32}$ Wade's view is unusually rigid both politically and legally. Politically, because it largely contradicts the traditions of the British system of government, according to which the making of any law, including constitutional law, is open to the political process. Legally, because it contradicts Dicey's established view that 'fundamental or so-called constitutional laws are under the constitution changed by the same body and in the same manner as other laws, namely, by Parliament acting in its ordinary legislative character'. ${ }^{33}$ It turns out then that although Wade and Dicey are taken to be advocating the same 'orthodox' view of parliamentary sovereignty, they actually disagreed fundamentally on the nature of constitutional change.

This debate is sometimes called the disagreement between 'self-embracing' and 'continuing' theories of parliamentary sovereignty. On the first view, a Westminster statute can change the way a Westminster statute is ordinarily made and operates, so its power 'embraces' itself. Hart called this the 'self-embracing' theory of parliamentary sovereignty and accepted it as a plausible interpretation of UK law. Hart correctly observed that once we abandon Austin's simple view of sovereignty, it would be 'equally conceivable' that the rule of recognition allows parliament to limit the legislative competence of its successors. ${ }^{34}$ We can make a choice, Hart says, between a 'continuing omnipotence in all matters not affecting the legislative competence of successive parliaments, and an unrestricted selfembracing omnipotence the exercise of which can only be enjoyed once'. ${ }^{35} \mathrm{~A}$ similar view was expressed by Ronald Dworkin, who noted that in the absence of a written constitution determining this question, there is no reason to believe that the constitutional rules of the United Kingdom cannot change through law. ${ }^{36}$

31 Wade's views are to be found in H. W. R. Wade, Constitutional Fundamentals (London: Stevens, 1980); and Wade, 'The Basis of Legal Sovereignty'.

32 Wade, 'The Basis of Legal Sovereignty,' 187-8.

33 Dicey, Introduction to the Study of the Law of the Constitution, 37.

34 For other versions of the 'self-embracing' view see Latham, The Law and the Commonwealth, 522-525; R. F. V. Heuston, Essays in Constitutional Law, 2nd ed. (London: Stevens, 1964), 1-3; Sir Ivor Jennings, The Law and the Constitution, 4th ed. (London: University of London Press, 1952), 146-9; and Geoffrey Marshall, Constitutional Theory (Oxford: Clarendon Press, 1971), 35-57.

35 Hart, The Concept of Law, 149.

36 See Ronald Dworkin, 'Does Britain Need a Bill of Rights?' in Dworkin, Freedom's Law: The Moral Reading of the American Constitution (Oxford: Oxford University Press, 1999), at 360. Dworkin commented on British constitutional law and the possibility of a more substantial constitution in 'Political Judges and the Rule of Law,' in Ronald Dworkin, A Matter of Principle (Oxford: Clarendon Press, 1985), 7-32. 
Wade, on the other hand, endorsed the 'continuing' view, namely the view that the status of an Act of Parliament cannot be determined by another Act of Parliament. This means that the Westminster Parliament cannot change the terms of its own supremacy. Wade accepted this unusual limitation as a reasonable price to pay for the clarity of constitutional law in a system without a written constitution. He was thus led to the view that sovereignty is not an ordinary legal rule. It is an immutable fact on which the unwritten constitution is based. For that reason, Wade thought that the Factortame decision of the House of Lords - the decision that accepted the supremacy of EU law over an Act of Parliament - was a true legal revolution, a legally unprincipled change of the rules. ${ }^{37}$ For Wade, strictly speaking, there is no law of constitutional amendment in the United Kingdom. Social change is a necessary and sufficient condition.

It is somewhat inaccurate, however, to call this view one of 'continuing' sovereignty. The way in which sovereignty operates does not remain unchanged through this process. For example, accession to the European Union and the creation of the Human Rights Act have modified the way the constitution works. In each case change happened through a simple Act of Parliament. It was supplemented by one or more judicial decisions of the highest appeals court. On Wade's view, while these changes seem incremental, they are in reality legal 'revolutions'. But since these revolutions have become regular events, it is incorrect to call this theory one of 'continuing sovereignty'. It is a theory of constantly shifting sovereignty. The only thing continuous about it is its dependence on some background fact. There is no reason to call this dependence 'sovereignty'.

Wade's view is now widely considered to be an eccentric view of the law. It was unanimously rejected by the House of Lords in the Jackson judgement on the validity of the Hunting Act. ${ }^{38}$ In that case the court endorsed Dicey's view, namely that the constitution of the United Kingdom is inherently flexible, which means that an Act of Parliament can change the constitution without any other formality or test. The House of Lords made no mention of the 'social change' view and did not even entertain the possibility that the Parliament Acts, which changed the way in which an Act of Parliament was made, was a revolutionary change, which went beyond the formal legal process. The Jackson ruling was strengthened by the HS2 judgment of 2014, which introduced the idea that the constitution distinguishes between 'constitutional instruments' and 'ordinary' laws. ${ }^{39}$ Most constitutional lawyers, though not all, agree with this interpretation of English law and

37 H.W.R. Wade, 'Sovereignty - Revolution or Evolution,' 112 LQR (1996): 568, discussing R v. Secretary of State for Transport ex parte Factortame Ltd (No. 2) [1991] 1 AC 603.

38 R(Jackson) v. Attorney General [2005] U.K.HL. 56.

$39 R$ (on the application of HS2 Action Alliance Limited) (Appellant) $v$. The Secretary of State for Transport and another (Respondents) [2014] UKSC 3, [2014] 1 WLR 324, par. 206 (Lord Neuberger and Lord Mance, with whom Lady Hale, Lord Kerr, Lord Sumption, Lord Reed and Lord Carnwath agreed). For an analysis of the judgment, see Paul Craig, 'Constitutionalizing Constitutional Law: HS2', Public Law (2014): 373. 
accept the idea that constitutional amendment is primarily or exclusively a legal process. $^{40}$

Yet, we are now left with a serious problem. As we have seen, if we endorse Austin's 'factual' view of sovereignty or Hart's 'legal view' of sovereignty, the most salient form of constitutional change would be a causal change in the underlying fact that makes the constitution possible. If the constitution rests on converging beliefs, then a change in the converging or diverging beliefs would change the constitution. This account invites all officials to form their own judgment about public sentiment and the level of support it gives to our basic institutions. There is no guarantee that the transformations in the social convergence that makes law possible will be rare. A legal revolution will always be in the cards.

If, for example, the required consensus is absent, then there is a legal 'revolution' and the old law disappears. The content of this revolution may be entirely negative. There may be no new consensus forming, and so no law left to take the place of the old, now obsolete, arrangement. For new law to emerge, we need a sufficiently coherent set of actual beliefs and attitudes. A new legal order is possible only under some new convergence, which is sufficiently solid to sustain a new constitution. But if the constitution moves with the tide of public sentiment, its long term stability would be very unlikely.

The problem is that such thought processes are foreign to constitutional law. Nothing like this kind of examination of underlying facts takes place. We do not test the constitution on the basis of its popularity. It exists regardless. In practice, all judicial decisions consider the constitution to exist as a matter of law. The British constitution, for example, is taken to apply to its own creation and amendment. This is the case for all constitutions, written or unwritten. The constitution must apply to its own change because otherwise it is not fully law. Hence, the factual account of sovereignty that emerges through the Austinian or Hartian theory of law, fails as an account of constitutional law.

Such theories end up undermining the idea of constitutional law. They tell us that the law is so much in flux and so much open to the ebb and flow of power, that the very distinction between the constitution and ordinary law or the distinction between the constitution and public opinion is open to indefinite and informal revision. This, more or less, follows from what Austin, Hart and Loughlin are saying. Loughlin alone, however embraces this finding wholeheartedly. He considers it an inescapable condition of political life. Under these views, the omnipotence, one way or another, of 'constituent' power is thus inescapable. The constitution

40 A theorist that seems to, more or less, side with Wade is Nicholas W. Barber, 'The Afterlife of Parliamentary Sovereignty,' International Journal of Constitutional Law, 9 (2011): 144. In the United States the best known proponent of regular extra-legal constitutional change is Bruce Ackerman. See Bruce Ackerman, 'Higher Lawmaking,' in Responding to Imperfection: The Theory and Practice of Constitutional Amendment, ed. Sanford Levinson (Princeton: Princeton University Press, 1995), 63-88; and Bruce Ackerman, We The People: Transformations (Cambridge, Mass.: Harvard University Press, 1998), 3. 
exists not as law, but as something like a cover for power. As Alf Ross puts the same point, the transition to a new legal order cannot be the outcome of a legal process but it is a fact, the socio-psychological fact that the community now accepts another custom as law or another basic norm as the corner-stone of its legal order'. ${ }^{41}$

This conclusion is fatal, however, to the idea of constitutional law. The idea of a higher law of the constitution, which is the ultimate law about law, assumes that all constitutional amendments should be legal in the mode of the self-embracing theory. Austin, Hart and MacCormick seem to be telling us that this is not possible. At the end of the chain there is a law-making fact. Constitutional change and constitution-making as a whole are thus ultimately matters of fact. So the constitution is and is not law. Loughlin sees and accepts this conclusion, which he calls the 'paradox' of constitutionalism. The paradox is that the constitution is both power and law at the same time.

\section{The constitution as higher law}

Is there a way of avoiding Loughlin's paradox and the conclusion that the constitution is not really law? Is there a way of showing that its claims to be selfembracing are not incoherent? I think there is, but it requires looking at law in an entirely different way. Austin, Hart, MacCormick and Loughlin are legal positivists and effectively legal empiricists. As we have seen, they view law as the result of some fact of authorship or other relevant fact. It is this assumption, a key thesis of legal positivism that creates the incoherence in constitutional law. The theory suggests that some relevant fact makes the law possible, creates it and determines its content and meaning. It is not simply the trigger for a legal order to exist, but the precondition for all legal rules and standards to exist. Sovereignty is presented by Austin and Wade as the cause of the law and the origin of its validity. A required convergence in opinion and belief is the cause of the law or rule of recognition for Hart and MacCormick. For Loughlin, 'constituent power' is the cause of a constitution. But if sovereignty or constituent power are causes of the law then they remain outside the law. And if they are outside the law, the constitution is not determined by law but by some extra-legal event. And if the constitution is created by a chain of events and not by legal tests of validity, then it is not fully law. It fails in its claim to be comprehensive: it determines all law except itself. Constitutional law becomes to that extent incoherent because it both is and is not the ground of all law. This is accepted by positivist theorists, who are happy to live with this instability.

It is not accepted, however, by judges or practitioners. All the judges who have looked at constitutional change in the United Kingdom have held that the constitution changes only through law. It is law all the way down, so to speak. It is always 'self-embracing'. They have never sought support in a causal story that 
explains validity through some extra-legal event. ${ }^{42}$ The House of Lords thus heard legal arguments about the status of the constitution and its change in Jackson and concluded that the way we make Acts of Parliament had changed through legal means, not through extra-legal revolutions. In a parallel judgment, in the case of HS2, the Supreme Court ruled that there is a distinction between higher and ordinary law in the constitution of the United Kingdom, which was the result of gradual legal change. These constitutional changes were legal. They were not considered to be 'extra-legal' revolutionary changes, as Wade believed. Just as with constitutions in other jurisdictions, the British judiciary has taken the constitution of the United Kingdom to be law in the full sense, with all that that entails. It is made according to law, amended according to law and has effects according to law. So in legal practice, the constitution is not an external cause of law but part of it. ${ }^{43}$

The trouble here is, as Kelsen has explained in great detail, that if the constitution is fundamental law, i.e. the law that tells us how all law is made, then there is no way of saying how the constitution itself is made without circularity. ${ }^{44}$ The existence of a written text is never the complete answer. But legal orders around the world, in the UK, Israel, India, Germany and perhaps the US, are united in assuming that this may not be a problem at all. The circularity of the constitution says that the constitution exists as a matter of law and the law exists as a matter of the constitution. If constitutional law is a law that tells us how all law is made and applied, then the creation and amendment of the constitution must itself be a fully legal matter and the constitution must apply to itself. But this does not create any problem in practice. This is what all the courts that have looked at the matter have said. It is not a problem if one considers the constitution a question of legal reasoning and argument, just like any other.

Practitioners seem to endorse a rival account of law, which I shall call a moral or practical account. This is a theory of law that predates legal positivism. It has been recently proposed by theorists such as Ronald Dworkin and Nigel Simmonds. ${ }^{45}$ They follow arguments made earlier by Locke, Rousseau, Kant, Rawls, and others,

42 Lord Mance's reference to the rule of recognition in Pham being perhaps one exception. See Pham v. Secretary of State for the Home Department [2015] UKSC 19, at para 80, where he said: 'For a domestic court, the starting point is, in any event, to identify the ultimate legislative authority in its jurisdiction to the relevant rule of recognition... But unless and until the rule of recognition by which we shape our decisions is altered, we must view the United Kingdom as independent, Parliament as sovereign and European law as part of domestic law because Parliament so willed'. Nevertheless, I consider it unlikely that an occasional remark could signal acceptance of an empirical theory of the constitution.

43 The leading exponent of this view in the English judiciary is Sir John Laws, whose judgments have led the way in numerous areas of English public law. For his general view of the constitution, see John Laws, The Common Law Constitution (Cambridge: Cambridge University Press, 2014).

44 See Hans Kelsen, 'The Function of a Constitution,' trans., I. Stewart in Essays on Kelsen, ed. Richard Tur and William Twining (Oxford: Clarendon Press, 1986), 109. See also for a similar analysis Ross, 'On Self Reference and a Puzzle in Constitutional Law,' 4.

45 In works such as Ronald Dworkin, Law's Empire (London: Fontana, 1986) and Nigel E. Simmonds, Law as a Moral Idea (Oxford: Oxford University Press, 2007). 
according to whom legal institutions are part of practical reason and need no causal background to explain how they proceed to make valid propositions of law. This theoretical view has been further explored and applied in constitutional law by constitutional scholars on both sides of the Atlantic, such as Ronald Dworkin, Lawrence G. Sager, David Dyzenhaus, T. R. S. Allan and many others. These theorists outline a moral theory of the constitution and explain how constitutional law works out its principles not as the product of some empirical fact, but as direct constructions of political morality. ${ }^{46}$ For these theorists, once we abandon the causal paradigm, the circularity of law and the constitution can be seen to be a strength and not a problem.

How can we overcome Kelsen's warnings about a vicious circle? It has seemed to many that the only way would be to replace the causal chain with another kind of chain, where the foundation is some fundamental moral principle. But how can this principle be vindicated? Are we not committing ourselves to the worst excesses of natural law and the presupposition of some 'self-evident' truths, as in the arguments of classical natural law revived by John Finnis? ${ }^{47}$ Unlike pure ethical thinking, legal reasoning must have a grounding in political decisions. This problem has been greatly illuminated by a discussion of the self-reflexive nature of law by N. E. Simmonds. ${ }^{48}$ His response is that there is no foundational principle. Law, as all moral reasoning, is a dialectical, interpretive or self-reflexive practice of reasoning. However, because law as a moral idea requires that we take disagreement, compromise and political decision-making seriously, it also requires that we consider actual law-making or decision making under law as something with moral weight. The ideal of law requires us to respect the fact that legitimate, if imperfect, legal institutions are in place.

Simmonds starts from the observation that Hart's theory of the rule of recognition amounts to a denial of the reflexivity of law. Hart sees legal thought 'as fundamentally guided by a basic rule accepted by officials: it is not guided by, and does not require, reflection on the nature of law as such. ${ }^{49}$ Simmonds argues, against Hart, that legal practices are oriented towards the ideal of law in the sense that the ideal is the basis of any authority that the practice possesses and to which its participants make appeal. But being directed towards an ideal does not mean presupposing any fundamental form of the ideal. The abstract ideal and its particular manifestations in legal practice are connected. ${ }^{50}$ The reasoning from

46 See for example Eisgruber, Constitutional Self-Government; Lawrence G. Sager, Justice in Plainclothes: A Theory of American Constitutional Practice (New Haven: Yale University Press, 2004); David Dyzenhaus, 'The Idea of a Constitution,' in Philosophical Foundations of Constitutional Law, ed. David Dyzenhaus and Malcolm Thorburn (Oxford: Oxford University Press, 2015), 9; and Allan, The Sovereignty of Law.

47 John Finnis, Natural Law and Natural Rights (Oxford: Clarendon Press, 1980).

48 See Nigel E. Simmonds, 'Reflexivity and the Idea of Law,' Jurisprudence 1 (2010): 1-23.

49 Simmonds, 'Reflexivity,' 2.

50 For a similar point, see the interesting arguments made in Stuart Lakin, 'Defending and Contesting the Sovereignty of Law: The Public Lawyer as Interpretivist,' 78 Modern Law Review (2015): especially 549-570, at 566-9. 
ideals to practices is always constant. Law is a process of reflection that turns to itself, like every other process of practical reasoning. ${ }^{51}$ What counts as a constitution, therefore, is not merely a matter of an earlier event of somebody 'causing' it to exist or of someone 'authoring' it in the way that an author creates a text. It is not an ideal blueprint on the basis of some philosopher's vision either. It is a process of reflecting on the ideal as well as the practice of a constitution. The reflexivity is therefore between abstract ideals of constitutionalism or legality as explored by philosophical reflection and the embedded practices of a particular jurisdiction.

Legal reasoning seeks two things at the same time: first, to interpret law as a moral idea and, second, to recognise the authority of established legal institutions as they are delivered to us. Simmonds concludes that the 'project of reflection upon the idea of law is in that sense inherent in the practices of law' so that law is invoked as a justification for the exercise of any state power. ${ }^{52}$ The justificatory project is constant; it has no beginning and no end. He concludes: 'In seeking a philosophical understanding of the nature of law we simply take seriously, and extend, the justificatory project that begins in the judicial judgment: for we endeavour to explain how law, by its very nature, provides a justification that can be invoked by the judge'. ${ }^{53}$

The argument illustrates the distinct practical problem faced by any citizen under the rule of law. The problem is how to act well while at the same time respecting political decisions reached by legitimate institutions in place. ${ }^{54}$ The answer cannot be that we only accept the decisions that accord with our immediate or abstract moral ideals. This would amount to denying all authority to our existing political institutions. The answer is that each jurisdiction has to deploy both abstract ideals and the particular interpretations of these ideals that are evident in its own collective practices, as long as these practices meet tests of legitimacy. There is, of course, no blueprint for pursuing this task successfully. It is an interpretive task that can succeed or fail.

This is the key idea, in my view, in the process of understanding constitutional law as self-embracing law. The constitution is a judgment or a series of connected

51 Simmonds' analysis echoes some of the points about legal interpretation made by Hans Georg Gadamer in Truth and Method, 2nd ed. , trans. Joel Weinsheimer and Donald G. Marshall (New York: Continuum, 1996), 324-40, where Gadamer speaks of the 'hermeneutic circle' as it applies to law. Support for this 'constructivist' way of thinking about practical judgment that is guided both by abstract ideals and examples from practice is found in recent accounts of ethics inspired by Kant, for example Barbara Herman, The Practice of Moral Judgment (Cambridge, Mass.: Harvard University Press, 1993); and Onora O’Neill, Constructing Authorities: Reason, Politics and Interpretation in Kant's Philosophy (Cambridge: Cambridge University Press, 2015).

52 Simmonds, 'Reflexivity,' 7. Simmonds uses this argument to show the shortcomings of Hart's and Raz's legal theories in a subtle and sophisticated argument which I cannot reproduce here. He shows how legal reasoning proceeds through the interpretive or dialectic interplay between abstract premises and concrete judgments.

53 Simmonds, 'Reflexivity,' 7.

54 Similar answers to the same question have been given in Dworkin, Law's Empire. 
judgments. It does not arise because of an event. It is not created by an act of authorship. The judgments of the constitution are both about abstract ideals and about concrete practices. The authority of the constitution is thus derived from within legal deliberation, in a reflexive process of reasoning that seeks to balance the requirements of abstraction with the requirements of practice. The constitution emerges through legal interpretation in light of all the relevant reasons that apply to us. The constitution is higher law and is self-embracing precisely because it is self-reflexive deliberation. Simmonds' argument effectively situates law in its social and political context. Because the ideal of law makes room for legitimate institutions of law, i.e. offices of law that create, enforce and interpret the law with authoritative force, we then see that our institutions have moral weight. Our existing institutions bind us both because they are legitimate and because they have been created by our political community. In this sense, the priority or validity of the Constitution is the result of a reflexive, deliberative judgment. Because the constitution is a practical judgment we make in light of the relevant values and the relevant facts, it needs no author. It is the product of practical judgment. Just like any other ethical idea, the constitution is a construction of reason in a process of deliberation. ${ }^{55}$ The constitution is higher law because this is its appropriate practical role.

\section{Constructivism and legal institutions}

If the constitution has no causal foundations, how are we to determine what it is? An ethical theory of law like that advocated by Dworkin and Simmonds is open to the charge that it invites wishful thinking into law. We all start from different ethical priorities and assumptions. Are we simply to assume that our best conception of the ideal constitution is our inevitable starting point for all judicial decisions? That some model of the good or blueprint for an ideal society is the only basis for law, to be imposed perhaps on all other citizens, however unwilling? It would be absurd to believe that disagreement is an illusion or that some ethical theory can rise above all our disagreements.

I believe that we must begin from precisely the opposite assumption. We need to say that no such common theory of the good is available. If this is so, we must then begin from a theory that explicitly seeks a different ethical starting point, not that of a full theory of the good. One well-known way of doing this is the Kantian argument for law which proceeds from ethical constructivism about what is the right thing to do, not what is good in the world. ${ }^{56}$ The Kantian argument begins from the assumption that ethical pluralism or pluralism about the good is

55 The same conclusion is reached by a different route by Frank I. Michelman, 'Constitutional Authorship,' in Constitutionalism: Philosophical Foundations, ed. Larry Alexander (Cambridge: Cambridge University Press, 1998), 64.

56 For modern defences and manifestations of Kant's arguments about law, see A. Ripstein, Force and Freedom (Cambridge, Mass.: Harvard University Press, 2009); and Onora O'Neill, Constructing Authorities: Reason, Politics and Interpretation in Kant's Philosophy (Cambridge: Cambridge University Press, 2015). 
an inescapable element of the human condition. A supposed common realm of common or self-evident moral ideals, as assumed by some natural law thinkers, does not exist. We must begin with the thought that we are moral agents thinking for ourselves. We are independent, self-governing agents. We share the world with other free agents like us. If we are not to fall into obvious contradiction, we owe them equal moral standing as self-governing agents. This creates a formal constraint of reciprocity and equality. Our question then is this: what kind of social arrangements should there be for a community of equal and autonomous agents, as bearers of equal moral claims in the absence of a common ground of self-evident goods?

Kant's argument about law responds to this challenge with a formal argument about principles of constitutional justice. The argument is built on the formal assumption of the equality and reciprocity of persons as citizens. Its starting point is the equality of free agents and the absence of a dogmatic list of values or ends. Kant says that there is only one innate right, namely the innate right to freedom, which is as follows: 'Freedom (independence from being constrained by another's choice), insofar as it can coexist with the freedom of every other in accordance with a universal law, is the only original right belonging to every man by virtue of his humanity'. ${ }^{57}$ Kant's argument presupposes innate equality, that is, independence from being bound by others to more than one can in turn bind them. It also presupposes the idea of being one's own master (sui iuris), as well as the idea of being beyond reproach. ${ }^{58}$ A system of constitutional law is the response to the requirement that we respect the 'innate right to freedom' in a shared world. A purely private relation between two persons cannot possibly guarantee that their relations will respect their innate equality. A man who acts with respect towards all others has no guarantee that others will do the same towards him. He may be tempted to accept inequality out of some kind of virtuous self-sacrifice. But he has then violated the very terms of equal moral standing, because he has accepted that he can be the instrument of others. In a state of purely private monitoring and enforcement, there is no way of respecting equality. This is Kant's basic argument for creating law or 'public right' and a public and fair mechanism of law-making and law-enforcement which Kant calls the 'civil condition'.

This constructivist argument for law is thus not based on a dogmatic assumption that some values deserve priority. Its starting point is merely the statement of the problem of how to live side by side with other moral agents while respecting everyone's equal moral standing. Kant's answer is that this can only happen

57 MM, 6:238.

58 At the heart of Kant's argument is an ideal of dignity of all human beings: 'Every human being has a legitimate claim to respect from his fellow human beings and is turn bound to respect every other. Humanity itself is a dignity; for a human being cannot be used merely as a means by any human being (either by others or even by himself) but must always be used at the same time as an end. It is just in this that his dignity (personality) consists, by which he raises himself above all other beings in the world that are not human beings and yet can be used, and so over all things.' (MM, 6:462). 
through public institutions of law. He assumes that equality leads us to the 'universal principle of Right', which requires reciprocity under a universal law: 'Any action is right if it can coexist with everyone's freedom in accordance with a universal law, or if on its maxim the freedom of choice of each can coexist with everyone's freedom in accordance with a universal law'. ${ }^{59}$ The point here is that without legality, there is no equal citizenship. If equal citizenship has priority, then so does the constitution.

Simmonds explains the same Kantian idea in terms of an ideal of independence from the power of others. He argues that the ideal law respects the moral equality of agents as citizens, who disagree about the right and the good in a shared world. His view is that law 'represents the only possible set of conditions within which one can live in community with others while enjoying some domain of entitlement that is secure from the power of others'. ${ }^{60}$ From the idea of reciprocity, we are led to constitutional law. ${ }^{61}$ The argument is Kantian in inspiration and has been made in different ways by many different authors in recent times, including by John Rawls and Ronald Dworkin. We build an answer to a moral question by stating it clearly as a question. The question is how to have law and institutions for equal moral agents. The answer is a statement of the question in other words. We say that we must outline constitutional essentials that organise legality and jurisdiction in a way that could be accepted by moral agents on the basis of equality and reciprocity. Reflection about law starts with the statement of this problem of practical life, namely, of how to live together as equals. Constitutional law is its detailed solution.

How then does a constitution emerge? Because the constitution is as a matter of practical judgment about our common life, it changes only according to the principles of constitutional justice. These will be different in an established constitutional order or in an order that emerges from civil war. All we need to say at the most abstract level is that the constitution is a moral construction of political institutions that satisfy principles of legitimacy. Such institutions would, for example, satisfy the constitutional essentials of legality and jurisdiction as they apply among a community of equals. So we can say that a constitution exists when power and principle meet in the right way. Whether it exists is a judgment of practical reasoning, based on a public deliberative process that looks at both our most abstract values and our political experience. The relevant principles are the constitutional essentials for that state. For a constitution to be legitimate it must make good on its promise to treat people equally. It must have institutions of effective jurisdiction, or in other words, institutions that specify laws and exec-

59 MM, 6:230.

60 Simmonds, Law as a Moral Idea. In his view legitimate law 'forms part of a system of universality, necessity and independence: that is to say, a system of general rules and principles (universality) that are given peremptory force and are reliably enforced (necessity) as the only way in which political expression can be given to the idea of peremptory force (given the circumstances of the real world).' (p. 143).

61 I have given an account of reciprocity with special reference to the work of Lon Fuller in Pavlos Eleftheriadis, 'Legality and Reciprocity,' Jerusalem Review of Legal Studies 9 (2014): 1. 
utive decisions, and adjudicate coercive enforcement. These are the elements of a legitimate constitution. A constitution exists if the test of constitutional justice and legitimacy are met. As long as they are met, the constitution endures.

\section{Sovereignty and Its alternatives}

We can now return, after this necessary detour to legal and political philosophy, to our original question. What is the relevance of sovereignty? The key to the answer is our rejection of the legal positivist thesis. The constitution is not a causal chain of events. If law is a practical judgment and not the result of a causal chain, it does not need a factual foundation. Sovereignty or its equivalents in terms of a relevant factual basis of belief or 'constituent power' are therefore not required for a constitution to exist. A constitution relies on facts only in the sense that it requires legitimate political institutions actually operating in some place. But the fact that they exist features inside deliberation as an element of a practical argument. They do not determine alone the constitution's existence.

So MacCormick was right to say that sovereignty - or the state's political power can be shared or indeed be abandoned on the basis of abstract principles. Nevertheless, Loughlin was also right to say that the power to shape the architecture itself, the political power to create and determine what law is, must exist somewhere. If such constitutional power is absent, then there is no constitution. But Loughlin was wrong to assume that constitutional authority is a fact. It is not, it is a matter of law like all matters of law-making. A constitutional architecture applies to itself because our practical judgments apply to themselves. Our practical judgments about right and wrong are always self-reflexive. They proceed from the particular to the abstract and back again. Although legal reasoning engages with political power, it is not determined by it. There is no causal chain between power and validity, as suggested by the legal positivists. The relation between power and law is interpretive, not causal. The constitution is not the result of an event, it is a judgment of practical reason.

For the constructivist view that I have defended, the constitution sets out a comprehensive institutional architecture of social life in terms of a set of higher order rules, which outline principles and official roles that are necessary on the basis of equality and reciprocity for any legitimate scheme of social cooperation. All laws are thus subject to a constitution according to principles which outline the role of courts, legislature, government etc. for each time and place. It follows that the circularity of law and constitution, the fact that the law makes the constitution and the constitution makes the law, is not a vicious circularity. It is part of an ordinary process of deliberation that moral agents engage in on the basis of all their moral judgments. There is nothing unusual about it. This process of reflection is just what we call living for human beings.

Such a deliberative view of the constitution makes sovereignty the subject matter of law, not its master. Hart's view of the state is the direct opposite and for this 
reason it is false. In his clearest comment on the subject, Hart notes that an imaginary society run by an absolute sovereign Rex would have 'some of the important marks of a society governed by law' and a certain 'unity' so that 'it may be called a 'state'. ${ }^{62}$ For Hart, all that we need for such a unity is not equal citizenship or reciprocity but merely that its members obey the same person, even though they may have no views as to the rightness of doing so'. ${ }^{63}$ On this view, law is just the effective human arrangement that communicates directions from one powerful person to its subjects. But as we saw above, this way of looking at law without judgment and without deliberation does not explain how constitutional law stays together. The edifice of law, public or private, assumes deliberation about a particular ordering of social life which presupposes the distinction between higher and ordinary law, in that it subjects all official action of law-making, administration and adjudication, to a general framework of institutions at the service of equal rights. These self-embracing constitutional institutions are the conditions for political legitimacy. Constitutional law is therefore invested with a very distinct moral purpose: the construction of an effective and legitimate scheme of social co-operation that enables us to live side by side as free and equal citizens. Power alone cannot achieve this task. In this sense, legal reasoning just like moral reasoning needs no foundations. It is continuous with practical reason about how to be a person in the world. The constitution is a practical judgment, defended and justified like all others. 